九州大学学術情報リポジトリ

Kyushu University Institutional Repository

\title{
Pyrrole Compounds as Food Mutagens
}

\section{Kim, Eun-Ho}

Department of Food Science and Technology, Faculty of Agriculture, Kyushu University

Shinohara, Kazuki

Department of Food Science and Technology, Faculty of Agriculture, Kyushu University

Murakami, Hiroki

Department of Food Science and Technology, Faculty of Agriculture, Kyushu University

Omura, Hirohisa

Department of Food Science and Technology, Faculty of Agriculture, Kyushu University

https://doi.org/10.5109/23849

出版情報: 九州大学大学院農学研究院紀要. 31 (3)，pp.279-285，1987-03-10. Kyushu University バージョン：

権利関係 : 


\title{
Pyrrole Compounds as Food Mutagens
}

\author{
Eun-Ho Kim, Kazuki Shinohara*, Hiroki Murakami \\ and Hirohisa Omura ${ }^{\dagger}$ \\ Department of Food Science and Technology, Faculty of Agriculture, \\ Kyushu University 46-09, Fukuoka 812
}

(Received September 2, 1986)

\begin{abstract}
The mutagenicity of some pyrrole compounds were studied. Pyrrole compounds tested showed the mutagenicity on bacterial tester strains. Pyrrole and N-methylpyrrole had positive mutagenic activity on the ret-assay with Bacillus subtilis strains $\mathrm{H} 17\left(\mathrm{Rec}^{+}\right)$and $\mathrm{M}$ $45\left(\mathrm{Rec}^{-}\right)$in the absence of S-9 Mix. That pyrrole and $\mathrm{N}$-methylpyrrole which had mutagenic action also exhibited DNA-breaking ability in the presence of $\mathrm{Cu}^{2+}$ was confirmed by agarose gel electrophoresis. But, the mutagenic action of pyrrole-2-carboxylic acid by the ret-assay or DNA-breaking action was not confirmed.
\end{abstract}

\section{INTRODUCTION}

The mutagens formed during food production, preparation, heat processing and cooking have been studied by treating whole foods and by using model systems. The use of model systems, such as amino acid and sugar mixtures, allows greater control over the factors that cause mutagen production in whole foods. The model browning reaction products can be fractionated into different chemical groups (e. g. volatiles, melanoidins), for component identification by mass spectroscopy and gas chromatography. According to Stich et al. (1982), the compounds identified from carbonyl, acidic, basic and neutral volatile fractions of a simple glucose-lysine model browning system included aldehydes, ketones, furans, alcohols, pyrazines and nitrogen compounds.

We have demonstrated that the model browning reactions of amino acids with sugars under relatively mild heating conditions below $100^{\circ} \mathrm{C}$ produce some mutagenic intermediates such as reductones, furans ans thiazolidines (Shinohara et al., 1980, 1983a, 1986 ; Omura et al., 1983).

Recently, 20 pyrrole derivatives have been identified as occurring in food systems. They were identified in coffee (Merritt et al., 1963 ; Reymond et al., 1966 ; Stoffelsma et al., 1968), beef as roasted (Liebich et al., 1972 ; Watanabe and Sato, 1972 ; MacLeod and Coppock, 1977), beer (Harding et al., 1977), cake (Takei,1977), eggs as heated (MacLeod and Cave, 1976) and tobacco (Roeraade and Enzell, 1972), and are still currently being reported in foods. It is also interesting to note that all the food systems have undergone some degree of either thermal treatment or microbial activity.

Thus, it does not appear that pyrroles are present in fresh, raw foods. As reviewed

\footnotetext{
* Present address : National Food Research Institute, Ibaraki 305, Japan

$\dagger$ Reprint requests should be addressed to this author
} 
by Hodge et al. (1972), nonenzymatic browning reaction can lead to the formation of numerous flavor-porducing compounds, including pyrroles. This has been verified by numerous researchers in working with model browning systems.

Although pyrroles are widely distributed in foods, there have been few reports about their toxicological properties, including their mutagenicities and carcinogenicites. In the present study, we examined the mutagenicities of pyrrole and its derivatives by the ret-assay with spores of Bacillus subtilis and DNA-breaking test.

\section{MATERIALS AND METHODS}

Test compounds

Pyrrole, N-methylpyrrole and pyrrole-2-carboxylic acid were purchased from Sigma Chemical Co., St. Louis, Mo.

Microbial strains

Bacillus subtilis strains H 17 and M 45 (Kada et al., 1972 ; Sadaie and Kada, 1976) were kindly supplied by Dr. Tsuneo Kada, National Institute of Genetics, Mishima, Japan.

Preparation of lambda DNA

Double-stranded DNA from lambda phage was pourchased from Wako Pure Chemical Ltd., Osaka. The lambda DNA was prepared by the method of Goldberg and Howe (1969) from the bacteriophage lambda $\mathrm{cI}_{857}$ Sam 7 particles which were obtained from $E$. coli $\mathrm{M} 65$ and purified by $\mathrm{CsCl}$ buoyant density gradient ultracentrifugation.

The spore ret-assay

Assay was carried out as described by Hirano et al. (1982). An appropriate volume $(0.1 \mathrm{ml})$ of $9000 \times \mathrm{g}$ supernatant of rat liver homogenate and spores (each $0.1 \mathrm{ml}$ of a suspension of $2 \times 10^{7}$ spores per $\left.\mathrm{ml}\right)$ of $\mathrm{H} 17\left(\mathrm{Rec}^{+}\right)$or M $45\left(\mathrm{Rec}^{-}\right)$strain of bacillus subtilis are placed in an empty petri dish (90 mm diameter), then $10 \mathrm{ml}$ of molten broth medium (autoclaved with $0.8 \%$ Difco agar and kept at $43^{\circ} \mathrm{C}$ ) are poured in and mixed well. When the agar medium is well solidified (it is recommended to keep it at $4^{\circ} \mathrm{C}$ for $30 \mathrm{~min}$ ), a paper disk (diameter $8 \mathrm{~mm}$, thickness $1 \mathrm{~mm}$ ) is impregnated successively with $20 \mu \mathrm{l}$ of the cofactor solution (20 mg of G-6-P and $40 \mathrm{mg}$ of NADP per ml) and $20-50 \mu \mathrm{l}$ of chemical solution is plated. After $20 \mathrm{~h}$ incubation at $37^{\circ} \mathrm{C}$, the lengths of inhibition zones appearing around the disk are measured. The values of the $\operatorname{Rec}^{+}$ strain are compared with those of the $\operatorname{Rec}^{-}$strain. As a positive reference mutagen for the ret-assay, 2-aminofluorene and Trp-P-1 were used.

\section{S-9 Mix}

Liver homogenate (S-9) was prepared by the method of Ames et al. (1975) from the livers of rats treated with Na-phenobarbital and 5, 6-benzoflavone (Matsushima et al., 1976).

S-9 Mix contained (per ml) $100 \mu \mathrm{l}$ of S-9, $4 \mu$ moles each of NADPH and NADH, $5 \mu$ moles of glucose-6-"phosphate, $33 \mu$ moles of KCL, $8 \mu$ moles of $\mathrm{MgCl}_{2}$ and 100 $\mu$ moles of Na-phosphate buffer, $\mathrm{pH}$ 7.4. 
DNA-breaking test

DNA-breaking activity of pyrroles was tested by use of lambda phage DNA, according to the method as described before (Shinohara et al., 1983b). $20 \mu$ l of lambda DNA $(420 \mu \mathrm{g} / \mathrm{ml})$ in $20 \times$ HMP buffer ( $\mathrm{pH} 7.0)$ was incubated with $20 \mu$ lof the pyrroles solution and $20 \mu \mathrm{l}$ of $2.5 \mathrm{mM} \mathrm{CuSO}_{4}$ for $4 \mathrm{~h}$ at $37^{\circ} \mathrm{C}$. In control $20 \mu \mathrm{l}$ of HMP buffer and $20 \mu \mathrm{l}$ of distilled water were used in place of the reagent and $\mathrm{CuSO}_{4}$, respectively. The reaction was stopped by adding $10 \mu \mathrm{l}$ of $15 \mathrm{mMEDTANa}_{2}(\mathrm{pH}$ 7.0). DNA fragment, then produced were detected by agarose slab gel electrophoresis. Before applying the sample on slab gel, $10 \mu$ l of $0.05 \%$ bromophenol blue (BPB) solution was added to each sample as a marker of the mobility on gel. As pyrrloes were practically insoluble in water, they were dissolved in dimethyl sulfoxide (DMSO) and the breaking reaction
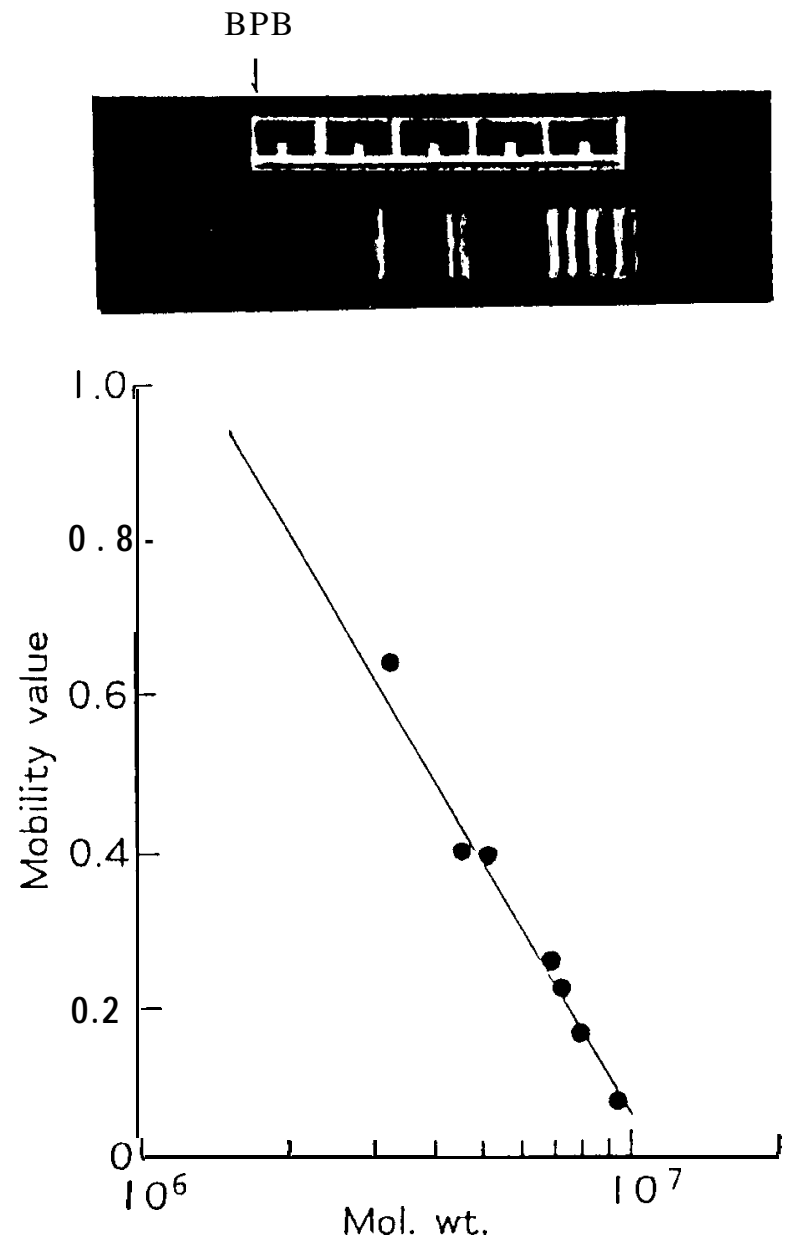

Fig. 1. Calibration curve of molecular weight of DNA on the agarose gel electrophoresis. 
was carried out in $20 \%$ DMSO.

Agarose slab gel electrophoresis

Electrophoresis was done on $0.7 \%$ agarose slab gel (Nakarai Chemicals Co.) using a horizontal electrophoretic apparatus with $89 \mathrm{mM}$ tris, $8.9 \mathrm{mM}$ boric acid and $2.5 \mathrm{mM}$ EDTANa $a_{2}$ (TBE buffer) containing $0.5 \mu \mathrm{g} / \mathrm{ml}$ ethidium bromide as a detecting fluorescence reagent of double strand DNA. Electrophoresis was carried out at room temperature for $12 \mathrm{~h}$ at a current of $50 \mathrm{~V} / 10 \mathrm{~mA}$. After development, DNA was visualized under irradiation with a short wave ultraviolet light source.

In order to quantitate DNA mass by densitometry, photographs of DNA-ethidium bromide complex were taken on Kodacolor VR film using a Nikon camera with red filter (Kenko Co.) under UV-irradiation with a Funa UV-light. The quantitativeness of this method was confirmed with known amounts of DNA. A calibration curve of molecular weights was made using lambda DNA fragments cleaved with restriction endonuclease Hind III. Molecular sizes of these marker DNA fragments ranged from $1.32 \times 10^{6}$ to $15.0 \times 10^{6}$ daltons. Mean molecular weights of DNA fragmants yielded by treatment with pyrroles solution were computed using the calibration curve and the densitometric data on the film (Fig. 1).

\section{RESULTS AND DISCUSSIONS}

The mutagenicities of pyrrole and its 2 derivatives were tested on the spore ret-assay and DNA-breaking test. The names and structures of the compounds are listed in Table 1 with the results of ret-effect and DNA-breaking action.

In the ret-assay the reference substance 2-aminofluorence gave inhibition zones of $6.5 \mathrm{~mm}$ in the $\mathrm{H} 17\left(\mathrm{Rec}^{+}\right)$strain and $14 \mathrm{~mm}$ in the M $45\left(\mathrm{Rec}^{-}\right)$strain. The diameters of the growth inhibition zones caused by the test substances are shown in Table 2 . Pyrrole and N-methylpyrrole dissolved in DMSO were estimated positive in this test however, they were slightly mutagenic without metabolic activation. Pyrrole-2-

Table 1. Structures and mutagenicities of pyrrole and its derivatives.

\begin{tabular}{lll} 
Chemical name & Rec-effect & $\begin{array}{c}\text { DNA breaking } \\
\text { action }\end{array}$ \\
\hline Pyrrole & + & + \\
Pyrrole-2- \\
carboxylic acid
\end{tabular}


Table 2. The spore rec-assay on pyrrole compounds.

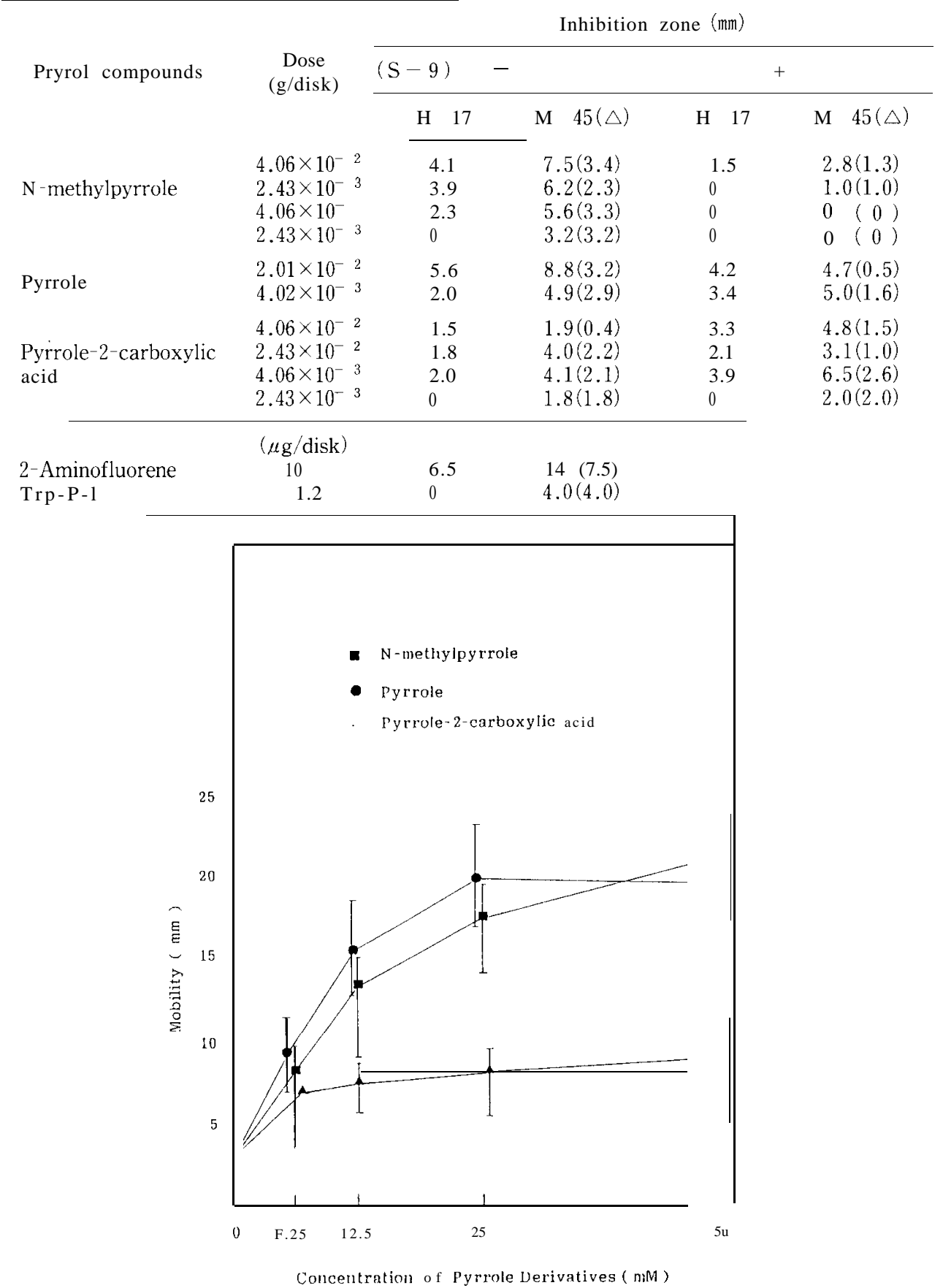

Fig. 2. Degradation of lambda DNA by pyrrole compounds in the presence of $\mathrm{Cu}^{2+}$. 
carboxylic acid in DMSO affected both strains to the same extent ; it therefore did not induce DNA damage that is detectable in this assay system. Metabolic activation did not enhance the activity of these chemicals.

As a second test system, the DNA-breaking test was used. Double-stranded DNA breakage by pyrroles was examined with lambda DNA. Fig. 2 shows the electrophoregram of DNAs treated with various concentrations of pyrroles in the presence of $\mathrm{Cu}^{2+}$. DNA-breaking action of pyrrole and N-methylpyrrole was very higher than that of control whereas the activity of pyrrole-2-carboxylic acid was so weak that no breakage was detected.

On the other hand, $\mathrm{Cu}^{2+}$ alone has no action on DNA molecules. These pyrroles were found to be inactive in DNA fragmentation without $\mathrm{Cu}^{2+}$. In general, pyrroles produced most highly fragmented DNA as concentration increased with $\mathrm{Cu}^{2+}$. The results indicated that these pyrroles, were able to split high molecular DNA strands to low molecular sizes with $\mathrm{Cu}^{2+}$.

Among the pyrroles tested pyrrole have been shown to be non-mutagenic to an Escherichia coli pol $\mathrm{A}^{+} / \mathrm{pol} \mathrm{A} \mathrm{A}^{-}$assay (Riebe et al., 1982). We have now found the mutagenicities of pyrrole and N-methylpyrrole, which have not been reported to be carcinogenic, were both mutagenic and produced DNA-breaking reaction. The results in the ret-assay and in the DNA-breaking test were very similar for the identical samples of compounds tested. Since pyrroles are present in various foods and may have human exposure, it is important that their distribution and biologic effects be determined.

\section{REFERENCES}

Ames, B. N., J. McCann and E. Yamasaki 1975 Methods for detecting carc $8 c z$ and mutagens with the Salmonella/mammalian microsome mutagenicity test. Mutation $8 E$ ru, 1:347-364

Goldberg, A. R. and M. Howe 1969 New mutations in the S cistron of bacteriophage lambda affecting host cell lysis. Virology, $38:$ ZOO-202

Harding, R. J., H. E. Nursten and J. J. Wren 1977 Basic compounds contributing to beer flavour. J. Sci. Food Agric., 28 : 225-232

Hirano, K., T. Hagiwara, Y. Ohta, H. Matsumoto and T. Kada 1982 Ret-assay with spores of Bacillus with and without metabolic activation. Mutation Res., 97 : 339-347

Hodge, J. E., F. D. Mills and B. E. Fisher 1972 Compounds of browned flavour derived from sugaramine reaction. Cereal Sci. Today, $17: 34-40$

Kada, T., K. Tutikawa and Y. Sadaie 1972 In vitro and hostmediated ret-assay procedures for screening chemical mutagens, and phloxine, a mutagenic red dye detected. Mutation Res., 16: 165174

Liebich, H. M., D. R. Douglas, A. Zlatkis, F. Muggler-Chavan and F. Donzel 1972 Volatile components in roast beef. J. Agric. Food Chem., $20: 96-99$

MacLeod, G. and B. M. Coppock 1977 A comparison of the chemical composition of boiled and roasted aromas of heated beef. J. Agric. Food Chem., 25: 113-117

MacLeod, A. J. and S. J. Cave 1976 Variation in the volatile flavour components of eggs. J.Sci. Food Agric., 27 : 799-806

Matsushima, T., M. Sawamura, K. Hara and T. Sugimura 1976 A safe substitute for poly chlorinated biphenyls as an inducer of metabolic activation system. In "Vitro Metabolic Activation in Mutagenesis Testing" ed. by F. J. de Serres, J. R. Fouts, J. R. Bend and R. M. Philpot, Elsevire, North Holland, Amsterdam, pp. 85-88 
Merritt, C., M. L. Bazinet, J. H. Sullivan and D. H. Robertson 1963 Mass spectrometric determination of the volatile components from ground coffee. J. Agric. Food Ckem., 11: 1522155

Omura, H., N. Jahan, K. Shinohara and H. Murakami 1983 Formation of mutagens by the Maillard reactions. ACS Symposium Series $215: 537-563$

Reymond, D., F. Muggler-Chavan, R. Viani, L. Vuataz and R. H. Egli 1966 Gas chromatographic analysis of steam volatile aroma constituents, application to coffee, tea and cocoa aromas. $J$. Chromatogr. Sci., $4: 28-31$

Riebe, M., K. Westphal and P. Fortnagel 1982 Mutagenicity testing, in bacterial test systems, of some constituents of tobacco. Mutation Res., 101: 39-43

Roeraade, J. and C. R. Enzell 1972 Tobacco Chemistry. XIV. Sampling, concentration, and examination of tobacco headspace vapors, J. Agric. Food Ckem., 20 : 1035-1039

Sadaie, Y. and T. Kada 1976 Recombination-deficient mutants of Bacillus subtilis. J.Bacteriol., $125: 489-500$

Shinohara, K., N. Jahan, M. Tanaka, K. Yamamoto, R-T. Wu, H. Murakami and H. Omura 1983a Formation of mutagens by amino-carbonyl reactions. Mutation Res., 122 : 279-286

Shinohara, K., M. So, M. Nonaka, K. Nishiyama, H. Murakami and H. Omura 1983b Electrophoretic study on the DNA-breaking actions of ascorbic acid and triose reductone in the presence of $\mathrm{Cu}^{2+}$.J.Nutr. Sci. Vitaminol., 29: 481-488

Shinohara, K., R-T. Wu, N. Jahan, M. Tanaka, N. Morinaga, H. Murakami and H. Omura 1980 Mutagenicity of the browning mixtures by amino-carbonyl reactions on Salmonella typhimurium TA 100. Agric. Biol. Ckem., 44: 671-672

Shinohara, K., E-H. Kim and H. Omura 1986 Furans as the mutagens formed by amino-carbonyl reactions. In "Amino-Carbonyl Reaction in Food and Biological Systems", ed. by M. Fujimaki, M. Namiki and H. Kato, Kodansha Ltd., Tokyo, pp. 353-362

Stich, H. F., M. P. Rosin, C-H. Wu and W. D. Powrie 1982 The use of mutagenicity testing to evaluate food products. In "Mutagenicity New Horizons in Genetic Toxicology", ed. by J. A. Heddle. Academic Press, New York, pp. 117-125

Stoffelsma, J., G. Sipma, D. K. Kettenes and J. Pypker 1968 New volatile components of roasted coffee. J. Agric. Food Ckem., 16: 1000-1004

Takei, Y. 1977 Flavor components of sponge cake and production of 2, 5-dimethyl-4-hydroxy-3 (2H)-furanone in several model systems. Agric. Biol. Ckem., 41: 2361-2368

Watanabe, K. and Y. Sato 1972 Shallow-fried beef: Additional flavor components. J. Agric. Food Ckem., $20: 174-176$ 